\title{
Self-Concept of Leaders in Administrative Units
}

UDK: 35-057.17

\author{
Jernej Buzeti
}

University of Ljubljana, Faculty of Administration

jernej.buzeti@fu.uni-li.si

\section{Janez Stare}

University of Ljubliana, Faculty of Administration

janez.stare@fu.uni-li.si

\section{ABSTRACT}

Within the leadership process, the positive self-concept of a leader can have an impact on quality reciprocal relations with subordinates and on the conduct of the leader and the subordinates. The results of the research into the selfconcept of administrative unit leaders indicate that the most poorly expressed areas of self-concept were the social and physical self-concept, while the highest was the general self-concept. Since it is important for leaders to have well developed skills, especially social skills and skills for working with people, the result of the research into the social self-concept of leaders in central government bodies (administrative units) is an important indicator of leaders' concepts of their own social image. The paper focuses on the self-concept of administrative unit leaders and presents results of research carried out in that field.

Key words: leader, social self-concept, physical self-concept, self-respect, administrative unit

JEL: $Z 00$

\section{Introduction}

Increasing attention is being paid to the importance of leading people and the adequacy of leadership both in the field of research as well as in practical implementation. The key factor in leadership is the leader, as the leader is the central point in relation to the people being led. Successful leadership of people requires leaders to have appropriate skills or 
competences, which have a significant impact on whether set objectives will be realised. Research confirms that leader personality has an effect on leadership effectiveness - and also that leaders form their self-image on the basis of their personality. This means their self-image or how they imagine themselves, their abilities, traits, their body, chances in life, successes and failures. The professional literature uses the term "selfconcept" to describe such traits. The leadership process is influenced by leaders' personality and their self-concept, since the self-image of leaders affects how they act, which is transferred to subordinates and their conduct.

\section{Leadership and leaders}

The literature indicates that there are various ${ }^{l}$ definitions of leadership that approach leadership from differing ${ }^{2}$ points of view. In this paper, leadership is understood as the influence of leaders on the people they lead with the aim of ensuring that those people would like (want) to carry out the tasks agreed with the leaders. Hellriegel \& Slocum (1996, pp. 445) offer a similar view, as they see leadership as influencing employees to act towards the realisation of objectives. Brajša (1983, p. 187) defines leadership as a complex, interpersonal process, since it involves working with people who are complex and demanding beings.

Northouse $\left(2007\right.$, p. 3) clarifies that the leadership is a process $^{3}$ in which a series of activities occur, as stated by Hočevar (2003, pp. 130131) and others sin a process in which leaders, the people led, and circumstances contribute equally«. The subordinates within an organisation or a social situation force the leaders to select an appropriate style of leadership - but leaders adapt their leadership style to the circumstances or situation in which activities take place in order to successfully realise an agreed or set task. Leadership is therefore a process that is defined by relations or interactions between the leader, subordinates and circumstances. The key factor in leadership is therefore a leader who, "setting an example and giving advice and instructions, ensures co-workers achieve a set organisational objective« (Stare \& Seljak,

1 Such as Bass, Antonakis, Yukl, Avolio, Bennis, Gardner, Kotter, Kovač, Mayer, etc.

2 Leadership can be addressed in terms of anthropology, psychology, sociology, technology, economics, or organisational, cultural or other studies

3 Similar views are offered by Bass (1990), Mayer (2004), Možina (1994), etc. 
2006, p. 89). Gibb (in: Nastran Ule, 1994, p. 237) states that a leader is:

- a dominant person with power and influence, with which he or she affects the behaviour and activity of others

- the "central person" for members of a group, an ego-ideal group

- the person who has most influence on others, and whose influence the group accepts voluntarily.

A leader defines important tasks in the leadership process and has a central role in an organisation or group. The leader's role is important, since leaders not only influence people in their achievement of objectives, but also act as an example to people (even in the field of morale and ethical standards). This is confirmed by Branden (2000, p. 61), who states that "too few leaders understand and appreciate the level to which they are an example to others. They do not recognise in how much detail the people around them sometimes unconsciously observe and take on their slight movements and how much their influence is expressed throughout the entire organisation. "What leaders do and say can often be detected in feedback in the conduct of the subordinates. This conduct is important and through experience we find that leaders must recognise and improve this kind of conduct. Leaders can affect conduct and leadership effectiveness via their abilities, knowledge and traits. ${ }^{4}$ Yet Stare (2005, p. 86) considers the abilities that an individual leader needs for successful leadership are difficult to unequivocally define, due in part to the influence of subordinates and individual situations.

Yukl (2002, p. 195) considers that human skills ${ }^{5}$ are vital to influencing people. These skills constitute knowledge and abilities needed to work in a group or the abilities needed to lead a specific group. They include skills ${ }^{6}$ held (or that should be held) by a leader in order to work with people, since they enable a leader to work more effectively with subordinates or the people they lead, all with the aim of achieving organisational objectives. Leaders with well-developed skills or abilities

4 Knowledge, skills and traits (personal, social) can be seen as comprising human potential.

5 In contrast to technical and conceptual skill.

6 Bass (1990, p. 195) defines them as "social skills" and considers that they refer to abilities that enable people to understand the feelings, mood and motives of subordinates and the abilities of good communication and persuasion. 
are aware of their own attitude and the doubts and convictions of other (subordinate) individuals and groups. They create a positive climate or atmosphere of trust in which employees (subordinates) feel comfortable and secure. These skills are important because they include motivating and understanding subordinates (according to Katz, 1955, pp. 34-35). Bass (1990, p. 110) states that research has indicated that such skills are extremely important and affect the performance and progress of leaders and leadership effectiveness. This is also confirmed by research carried out by Boyatzis (1982), which indicates that successful leaders are distinguished from unsuccessful leaders on the basis of human skills. Nastran Ule (1994, p. 237) clarifies that leaders' skills are linked to the tasks they must carry out and that important tasks are primarily psychological, social and professional.

Leadership performance is not only affected by leaders' skills and knowledge, but also by the leaders' traits. A review of the literature indicates that each individual author defines the traits typical of a successful leader from their own point of view. Table 1 sets out the views of a number of authors on the traits that a successful author should have.

Table 1: Key traits of successful leaders

\begin{tabular}{|l|l|l|l|}
\hline Northouse (2007) & $\begin{array}{l}\text { Kirkpatrick in Locke } \\
\text { (1991) }\end{array}$ & $\begin{array}{l}\text { Stogdill } \\
(1974)\end{array}$ & $\begin{array}{l}\text { Mayer } \\
(2004)\end{array}$ \\
\hline - intelligence & - drive & - achievement & - intelligence \\
- initiative & - motivation & - persistence & - personality in a \\
- decisiveness & - integrity & - insight & - creativity \\
- integrity & - confidence & - initiative & - expressiveness \\
- sociability & - cognitive ability & - responsibility & - empathy \\
& - task knowledge & - cooperativeness & - positive self- \\
& & - tolerance & concept \\
& & - sociability & - decisiveness \\
& & & - ethical principles \\
& & & altruism and \\
& & & philanthropy \\
\hline
\end{tabular}

Source: Northouse (2007, pp. 18-19), Mayer (2004, pp. 53-56)

Maxwell (2007, p. 10) identifies 21 important traits that successful leaders should have: character, charisma, commitment, communication, competence, courage, discernment, focus, generosity, initiative, listening, passion, positive attitude, problem-solving, relationships, responsibility, security, self-discipline, servanthood, teachability, and vision. Comparing 
traits indicates that all authors emphasize the trait of leaders' selfconfidence or respect for themselves and their abilities. According to Maxwell (2007, p. 101) a leader is someone who masters the "laws of leadership", but leaders only become effective because of what is within them. Leaders are therefore important as people with a clear understanding of themselves and what they want to achieve and with selfbelief. It is also important for leaders to have formulated an image of themselves.

\section{Self-concept}

The self-image of leaders or their self-concept in relation to subordinates is primarily important because it influences the leaders' conduct and consequently also influences the conduct of subordinates and the self-awareness and self-confidence of leaders within the framework of individual dimensions of their self-concept. Nastran Ule (1994, p. 238) clarifies that experts ${ }^{7}$ have found through research that good leaders have a well-constructed and realistic self-concept.

An individual creates a self-concept as a unique personality, which in Allport's opinion (Samuel, 1981, p. 3) represents the dynamic organisation of individual psychodynamic systems that define an individual's typical conduct and thoughts. And since people are social beings, since they establish relations with other people, the personality of each individual and the related self-concept influence the quality of establishing and maintaining relations with others. This is affirmed by Musek (2005, str. 1), who states that »only on the basis of an appropriate recognition of personality can we function well in mutual relations and order them as we want."

The leadership process also includes interaction between the leader and subordinates, i.e. relations between various personalities. Therefore an individual's personality and self-concept are important to the leadership process. Stare \& Seljak (2006, p. 189) clarify that »determining leadership potential is based on knowing personality or individual aspects of personality. «Rogers (in: Kohont, 2005, p. 36) states that an individual's conduct as a unique personality depends on what the individual thinks of his or herself and his or her experiences of self.

7 Nastran Ule (1994, p. 238) cites the following authors: Bird (1940), Mann (1959), Sorrentino and Boutillier (1975). 
There are numerous expressions used to define the idea of selfconcept in the Slovenian literature (according to Kobal, 2000, p. 17). Some use the term samoidentiteta (self-identity) (Musek, 1993a, p. 359), identiteta (identity) (Zupančič, 1993, p. 208), socialni jaz (social ego) (see Nastran Ule, 1994, pp. 292-302), samopercepcija (self-perception) (Ferbežer, 2008, p. 25). In the literature in English one finds self (James, 1890, Cooley, 1902), self-actualisation (Rogers, 1951, Maslow, 1954), self-image (Offer et al, 1988), self-concept (Shavelson \& Bolus, 1982), self-esteem (Rosenberg, 1965), identity (Kroger, 1989) and others.

The self-concept construct is addressed by numerous ${ }^{8}$ experts, and that is the reason for the plethora ${ }^{9}$ of terms used to define self-concept. What all these terms share according to Nastran Ule (1994, p. 296) is that the construct involves the many attitudes that individuals have towards themselves ${ }^{10}$. Individuals gradually enter these relationships via their feelings, impressions, assessments and evaluations of themselves, their typical social tendencies, which they develop from birth onward, first through a primal object, and later via the broader social environment. This is their sense of their own continuity in space and time and the fact that others also recognise that continuity. According to Kobal (2000, p. 24) the Slovenian term samopodoba is understood as combining two different concepts, the American self-concept and European self-image. Self-concept is defined as the conscious, conceptual and, therefore the logical and rational, while self-image emphasises the unconscious, instinctive and emotional. Both are a combination of the psychosocial, physical and behavioural dimensions of personality - self-concept. Tohme defines self-concept in a similar manner (Kobal, 1994, p. 31), as he clarifies that it entails a set of actions, images, characteristics, tastes, values, expectations and so on, which individuals are aware of to various degrees of clarity within themselves and appropriately organise and coordinate in relation to others and their own social roles.

Burns (1979) states that the "self-concept is an assembled image of what we think of what we are, what we think we could be or what

8 Shavelson, Marsh, Offer, Rogers, Markus, Wurf, Fleming, Watkins, Kobal Grum, Avsec etc.

9 This is also confirmed by Ahmed and Bruinsma (2006, p. 554).

10 The concept is described in a similar manner by Akram \& Akram Naseem (2010, p. 78). 
we could achieve, and what we think others think of us, and what we would like to be or what we would like to become«. Burnett $(1999$, p. 2) and others state that "self-concepts are the multidimensional descriptive, evaluative, comparative, cognitive beliefs that people have about specific characteristics. The three major characteristic areas are physical, social and academic." Zimbardo \& Gerrig (1996, p. 528) state that self-concept is a dynamic structure as it contains many components such as:

- people's own memories of themselves

- convictions or confidence in own traits, motives, values and abilities

- ideal "ego" or ideal self-concept, which they would like to achieve or acquire, and a potential "ego" or self-concept that they would like to act upon

- positive and negative evaluations of themselves

- and convictions about what others think of them.

To a considerable extent, self-concept is the product of social construction and social reflection - statements others make about us are like a mirror, in which we see ourselves. For this reason, Adlešič (1999, p. 5) states that wat the self-concept level, various socio-psychological processes have an impact such as receiving information from significant others, social comparison with others, assuming the roles, values and stances of the social environment in which the individual lives, and identification with a model.« Nastran Ule (2004, p. 296) also considers that sour self-concept is only confirmed by other people that we find interesting or important in some way. But they must do this without pressure or manipulation. Positive self-concepts that people gain by "bribing" others do not have sufficient value, since they can often be threatened by more autonomous and critical observers." The importance of the environment or other people on the development of the selfconcept is also defined by Musek (1993b, pp. 348-349), as he states that statements by others, such as how "good", "naughty" or "lively" we are, are imprinted into our self-concept. All these messages more or less "grip" our psyche and become part of the impression we cultivate about ourselves.

After reviewing the literature, we found that authors ${ }^{\prime \prime}$ largely pointed to childhood or adolescence as the key to the development of

11 For example Kobal, Juriševič, Lewis, Adams and Hurlock. 
self-concept. Adlešič (1999, p. 2) considers that self-concept development is continuous and typical of every period of development. This also means that despite the fact that childhood and adolescence are key periods for the development of the self-concept, adulthood is a period in which many new areas of self-concept are established, which are closely linked to the development of personality during adulthood. Kobal (2000, p. 89) states that self-concept develops with age, and as research shows, also changes and structures itself. It does not develop as a whole, but with age very different areas form, from physical and social to academic and emotional self-concepts and more. This is also affirmed by Shavelson (in: Adlešič, 1999, p. 4), who states that a self-concept forms gradually during human development - mainly on the transfer from childhood to adulthood; with age it becomes increasingly layered. The extent to which individuals structure or delimit their self-concept in individual areas depends on their adult lifestyle, their obligations, interests, social roles and engagement in reciprocal relations (see Kobal Grum, 2004, p. 99).

\subsection{Self-concept and self-respect}

Self-respect is an important correlate of self-concept representing its value aspects (according to Potočnik, 2003, p. 6). Kobal Grum (2003, p. 20) even considers that self-respect is the most important correlate of self-concept. If self-concept covers primarily neutral self-descriptions, then self-respect relates to value-based self-description, including extremely emotional attitudes to oneself. Self-respect is therefore a value-based attitude to oneself, and primarily covers the emotions people feel for themselves. There is also a positive correlation between self-concept and self-respect - a person who has a very positive self-concept (particularly in general), also has high self-respect. And the opposite applies; people who do not have a high opinion of themselves, do not value themselves much (Kobal Grum, 2003, p. 21).

Self-respect is a complex concept that includes attitudes, convictions, disposition, desires, expectations, emotions and acts that express or generate a feeling of personal value. It includes recognising and understanding personal value as well as the desire and disposition to protect and maintain that value (Marčič, 2006, p. 66). Rosenberg (Kobal, 2000, p. 154) describes self-respect as a positive or negative attitude to oneself. A positive attitude or high self-respect means that 
individuals accept themselves as they are, value themselves, are satisfied with themselves, and feel worthy of respect. People with low self-respect or a negative attitude to themselves do not value themselves, do not seem themselves as worthy and do not value their own traits. Self-respect is an attitude to oneself, and primarily covers the emotions people feel for themselves.

Rosenberg (1965) in one research work also proves that low selfrespect is linked to symptoms typical of anxiety: trembling hands, headache, increased heart-rate, etc. (Rosenberg in: Avsec, 2010, p. 98). Signs typical of people with a poor self-concept or low self-respect are jealousy, speaking negatively about themselves, feelings of guilt, inability to offer compliments, not taking account of own need, inability to ask for what they want, inability to express affection to others, a critical attitude to others, comparison with others, ongoing deterioration in health (Račnik, 2008).

Kobal (2000, p. 165) states that numerous researchers have found that the link between self-concept (self-respect) and anxiety are inversely proportional - the more an individual has a positively formulated selfconcept and high self-respect, the lower the level of anxiety. And conversely, the less a person values his or herself and feels valued, able and successful, the greater the anxiety.

\subsection{Areas of self-concept}

The structural models of self-concept of various authors ${ }^{12}$ indicate that self-concept is a psychological construct composed of differing areas or sub-areas. After reviewing the literature, we found that authors ${ }^{13}$ divide self-concept into areas such as general, social, physical, emotional, religious, academic, family self-concept, etc. The areas that comprise the self-concept differ with the individual's age and circumstances in which the individual operates or may differ ${ }^{14}$ from individual to individual. Through experience one can ascertain that the self-concept of each individual and hence the self-concept of each leader is comprised

12 Shavelson, Bolus, Offer, Tam, Watkins etc.

13 E.g. James (1980), Fleming and Elovson (1988), Kobal (2000), Hattie (2003) etc.

14 Hattie (2003, p. 7) lists 18 sub-areas for academic self-concept alone and states that there may be many more. 
primarily of general, academic, social, physical and emotional selfconcept. ${ }^{15}$

Emotional self-concept represents people's sense and conviction of the expression, understanding and control of their emotions. The individuals, for example, conceive of and see themselves as peaceful or not, relaxed or not and emotionally balanced or imbalanced. They also have a view on whether they are generally in a good or bad mood, whether they are deeply agitated and how they control their emotions (see Kobal, 2000, pp. 205-220). Social self-concept includes the perceptions, ${ }^{16}$ convictions and judgement individuals hold about relations with peers and other important "others", such as parents, siblings, partner and colleagues. These are their perceptions of their own friendshipmaking abilities and popularity and the quality of their relations with others. Part of the self-concept relates to individuals' influence on the broader community or their experience of their attitude to the law and social moral norms (Kobal, 2000, pp. 171-200). Musek (1993a, p. 345) ascribes considerable importance to the social self-concept and explains that part of the self-concept comes from the understanding and image people have of what others think of them and how they present and portray themselves to others socially - the social ego. Hattie (2003, p. 18) states that the social self-concept is important for individuals and that a great deal of information about each individual comes from social circumstances. Most people are frequently in the presence of others and their personality is also presented by others to third parties - on the basis of which the person builds and recognises him or herself in social situations and forms a self-image.

The sign of a good social self-concept in a leader is that they can easily form and maintain quality relations with subordinates. Leaders have a clearly formulated image of themselves and are not sensitive to the disproval of others, are not obsessed with how best to present themselves to the social environment. Leaders with a highly expressed or positive social self-concept do not have problems with anxiety or above all social anxiety, which means that people experience continual (unexplained) fear

15 The display of individual sub-areas comprising the self-concept differrs from individual to individual, as the number of areas may differ.

16 James (in: Hattie, 2003, p. 17) defined the social ego as a form of "acknowledgement" that we gain from those close to us (e.g. family, friends). 
of social situations in which others could assess or judge them. Fear of that kind increases, if they feel that they could be humiliated in front of such people. Leaders with social anxiety are unsuccessful in relations with people and frequently feel anxiety, tension and upset.

In Schilder's opinion (Fisher, 1990, p. 8) »physical self-concept [is] an individual's body image, created in their own thoughts. "Thompson (in: Kuhar, 2004, p. 84) and others have stated that "physical self-concept is a terminological symbol for a person's internal image of their own external appearance. This internal image or mental picture is linked to feelings and thoughts that affect conduct in certain situations. In some cases the feelings coming from the assessment of appearance are positive, in other cases they may be negative, which can even lead to depression." »A positive physical self-concept can even increase selfrespect and contribute to more successful reciprocal or business contacts, while a negative image of one's own body reduces self-confidence to such an extent that a person is not willing to leave the safe haven of their home« (Kuhar, 2004, pp. 84-85). Grogon (Kuhar, 2004, p. 86) considers that the physical self-concept involves shuman perceptions, thoughts or feelings about their body. Perceptions relate to assessment of body size, evaluating physical attractiveness and feelings about the emotions linked to body shape and size."

Mutual experiences, e.g. socialising, evaluating, even minor comments on appearance have a significant impact on the development of the physical self-concept. People subjected to frequent criticisms and teasing during childhood and youth due to their appearance develop a more negative physical self-concept, because one does not forget one's physical self-concept. Specific events and situations that lead to specific feelings and thoughts about appearance can also lead to a negative selfconcept (Kuhar, 2004, p. 87). Kobal (2000, p. 65) explains that if the formation of physical self-concept during adolescence is disturbed, then the general self-concept and self-respect cannot develop appropriately.

\section{Research on the self-concept of administrative unit leaders}

The purpose of the research presented in the paper was to emphasise the importance of leaders' self-concept. Leaders are people whose conduct affects the functioning (conduct) of employees and therefore the efficiency and effectiveness of the administrative unit. The main objective 
of the research or study was to determine the self-concept of administrative unit leaders and the areas of self-concept in which they scored relatively highest and lowest. The target group participating in the research were leaders performing similar tasks in central government bodies and performing them around the entire country. These conditions were met by administrative unit leaders and therefore leaders from Slovenian administrative units were included in the research sample.

The research was carried out across 57 administrative units (only one administrative unit decided not to participate) and 136 leaders took part in the research, of which fewer than $5 \%$ were both expert technical staff (civil servants) and heads of organisational units. The highest proportion, over $66 \%$, were officials or organisational unit heads with up to 30 employees. Half of all the administrative unit heads in Slovenia took part in the research or $21 \%$ of all surveyed leaders. Organisational unit heads with over 30 employees represent $8 \%$ of leaders assessed in the research.

The Questionnaire ${ }^{17}$ created as part of the research included 45 questions and measured four aspects of self-concept: general, social, physical and emotional self-concept. The concept for designed the question came from the Self-Respect Scale ${ }^{18}$ by Tanja Lamovec and the SDQIII ${ }^{19}$ questionnaire (questions used to define general self-concept). A high number of points or high average for each individual dimension of self-concept indicates that the self-concept is strongly expressed in this area.

\subsection{Research results}

The research was intended to determine how individual areas of selfconcept are expressed by leaders, and namely: general, emotional, social and physical self-concept. The research indicated that the social and physical self-concept areas scored relatively lower than general and emotional self-concept. The use of a $t$-test indicated that the only pair of self-concept areas that did not have a statistically significant difference was social and physical self-concept. Statistically significant differences were found for all other pairs of self-concept areas.

17 Called the Self-Concept Scale Questionnaire.

18 Abbreviated SRS.

19 Self Description Questionnaire III (Marsh, 1992) 
Graph 1: Self-concept areas for administrative unit leaders (average score)

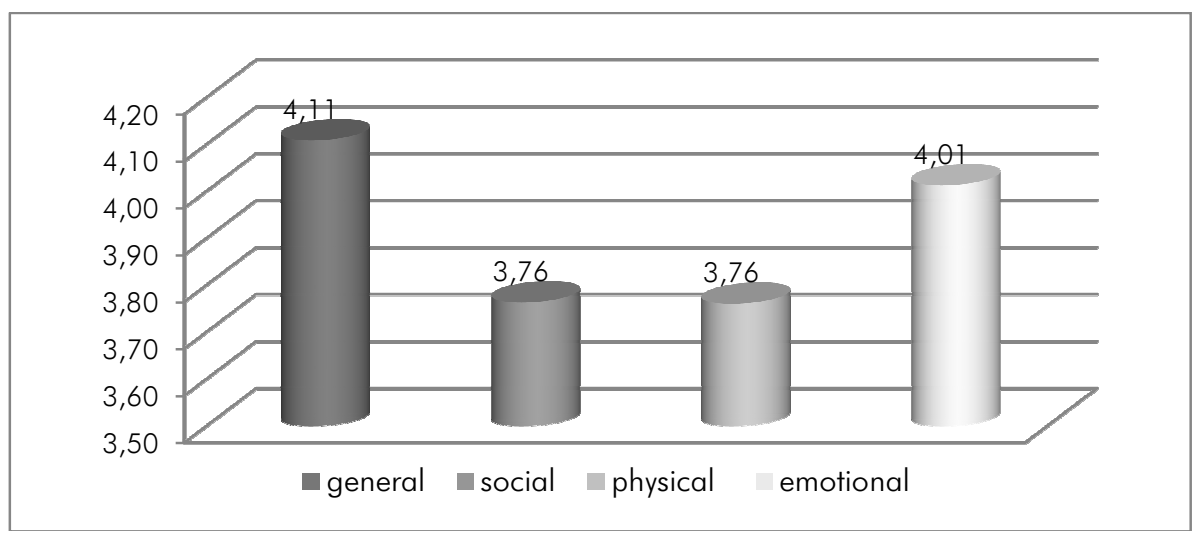

Source: own data

The research results (cf. Graph 1) indicate that the physical and social self-concept were the lowest scoring areas measured by the research, as the average leader score for both areas was 3.76. This result indicates a moderate expression of social and physical self-concept in the administrative unit leaders studied.

\section{Graph 2: Comparison of three statements as part of general self-concept}

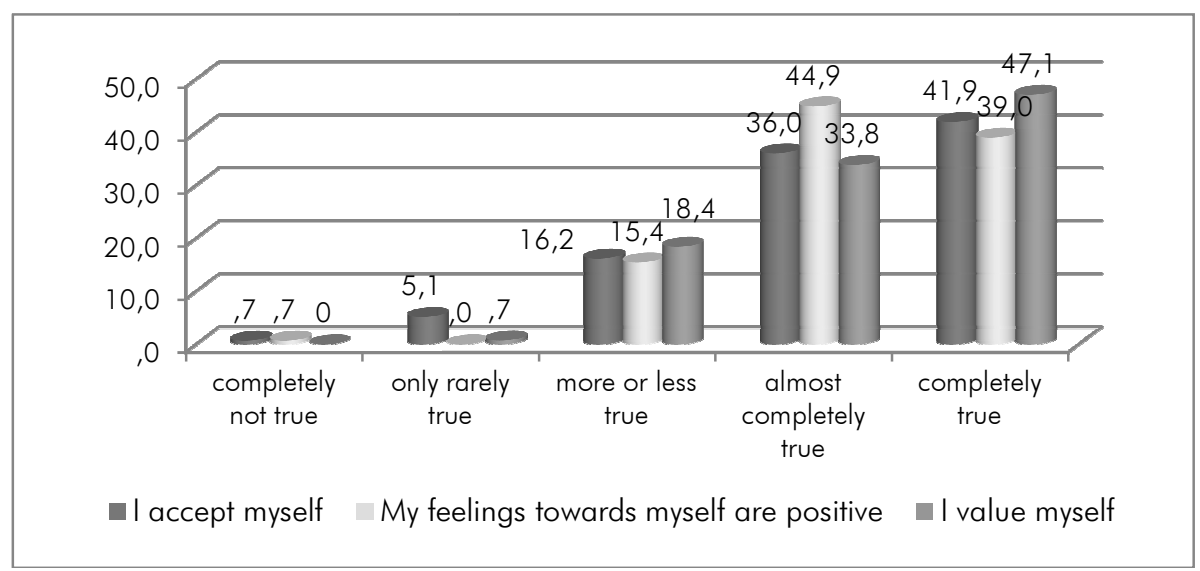

Source: own data

Among the general self-concept variables (cf. Graph 2), a statistically significant difference was found between two variables: "I accept myself" and "I value myself". No statistically significant difference was found between the remaining pairs of variables. The results for the pair with a statistically significant difference indicate that just under $67 \%$ of leaders studied stating they accept themselves, also stated that they value 
themselves, while $11 \%$ of leaders who accepted themselves considered at the same time that although they value themselves somewhat, they do not do so completely. Over $67 \%$ of leaders considered that they both accept themselves and also have positive feelings towards themselves.

Among the emotional self-concept variables, the highest scoring were "I don't think that I'm worthless" (4.38) and "I have no problems with depression" (4.32). The lowest scoring variables were "I think that I'm not excessively sensitive to the disapproval of others" with an average score of 3.57 and "I'm satisfied with myself" with an average score of 3.69. The $t$-test indicates that a statistically significant difference is found between the highest scoring variable and the lowest (cf. Graph 3).

\section{Graph 3: Comparison of two emotional self-concept variables}

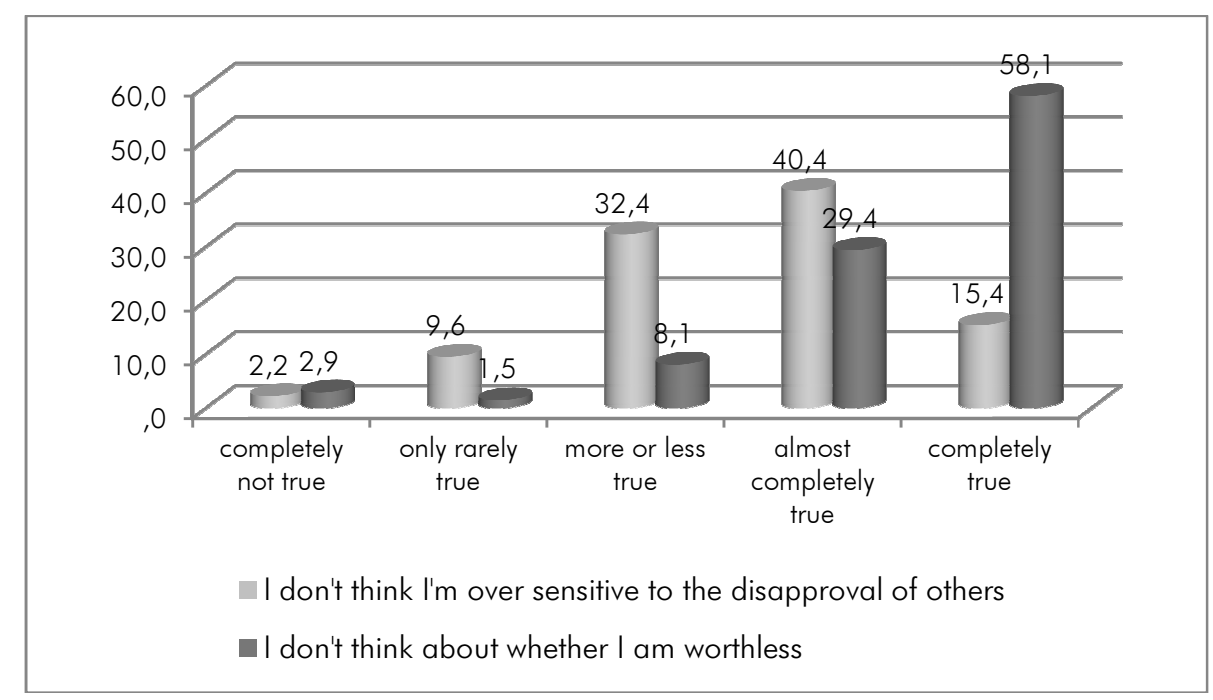

Source: own data

The results given in Graph 3 indicate that only just over 55\% of leaders consider that they are not sensitive to the disapproval of others. Over $11 \%$ of leaders are sensitive to the disapproval of others. A certain amount of leader sensitivity to the disapproval of others is necessary, since in that way leaders also sense and display their own emotions. However, what is more important than sensitivity to the disapproval of others is empathy or the ability to "put themselves in the shoes of" subordinates or recognise their emotions and needs. A certain level of sensitivity (or lack thereof) to the approval (or disapproval) of others can also be understood in this manner: leaders want to please others and since some others do not approve of them this will elicit certain feelings in leaders, and some 
are more sensitive to these feelings than others. An analysis of results also indicates that over $87 \%$ of leaders do not think about whether they are worthless. However, over $4 \%$ of leaders do think about whether they are worthless. Meanwhile, 52\% of leaders consider that they do not think about whether they are worthless, and also think they are not oversensitive to the disapproval of others. Over $9 \%$ of leaders, who do not think about whether they are worthless, do think they are oversensitive to the disapproval of others.

The $t$-test indicates that there is a statistically significant difference between the emotional self-concept variables that relate to depression and to tension and worry (cf. Graph 4).

\section{Graph 4: Comparison of two emotional self-concept variables}

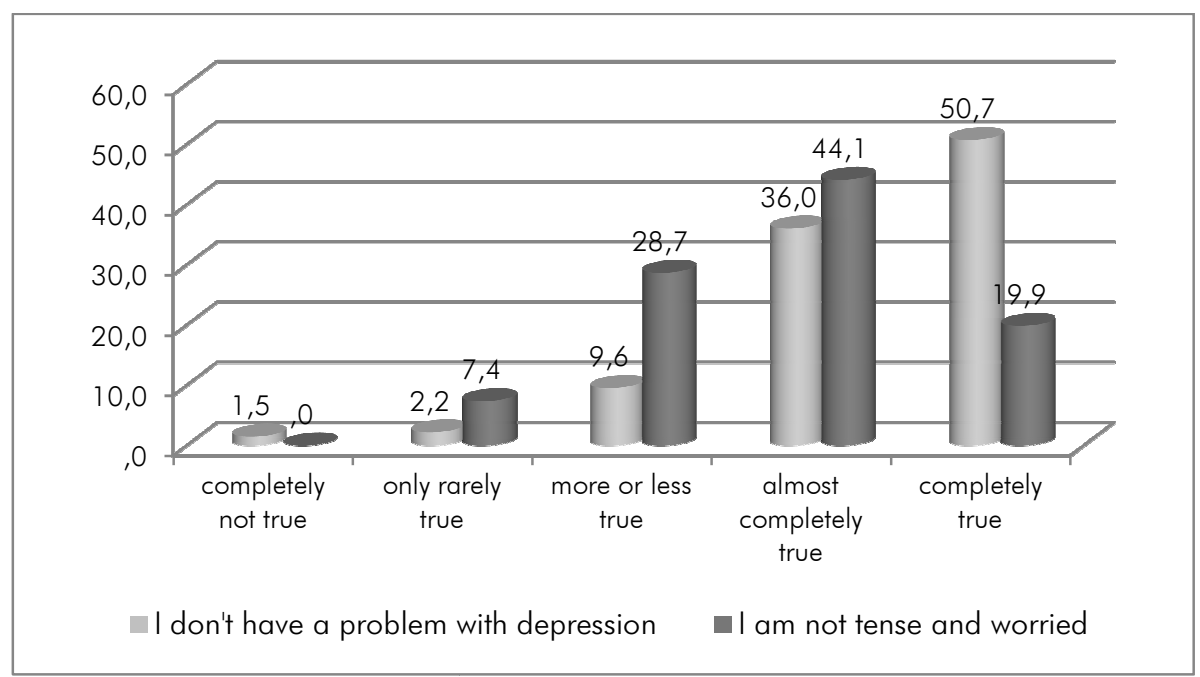

Source: own data

The results given in Graph 4 indicate that over $86 \%$ of leaders consider that they do not have problems with depression. One would expect that the percentage would be about the same for the statement "I am not tense and worried", the content of which is closely linked to depression, however, as the results indicate, only $64 \%$ of leaders consider that they are not tense and worried. Over $61 \%$ of leaders who said they were not tense and worried also said they had no problems with depression. Under $3 \%$ of leaders who stated that they had no problems with depression assessed themselves as tense and worried. Over $2 \%$ of assessed leaders considered they had problems with depression and that they were also tense and worried. 
The results for the social self-concept variables indicate that the social self-concept of leaders is not highly expressed or scores moderately, which is cause for concern. The t-test indicated that statistically significant differences exist between some variables. A statistically significant difference exists between the variables "I'm not worried if I don't get on very well with other people" and "I'm not worried by the thought of people at work judging me as successful or unsuccessful" (cf. Graph 5).

\section{Graph 5: Comparison of two social self-concept variables}

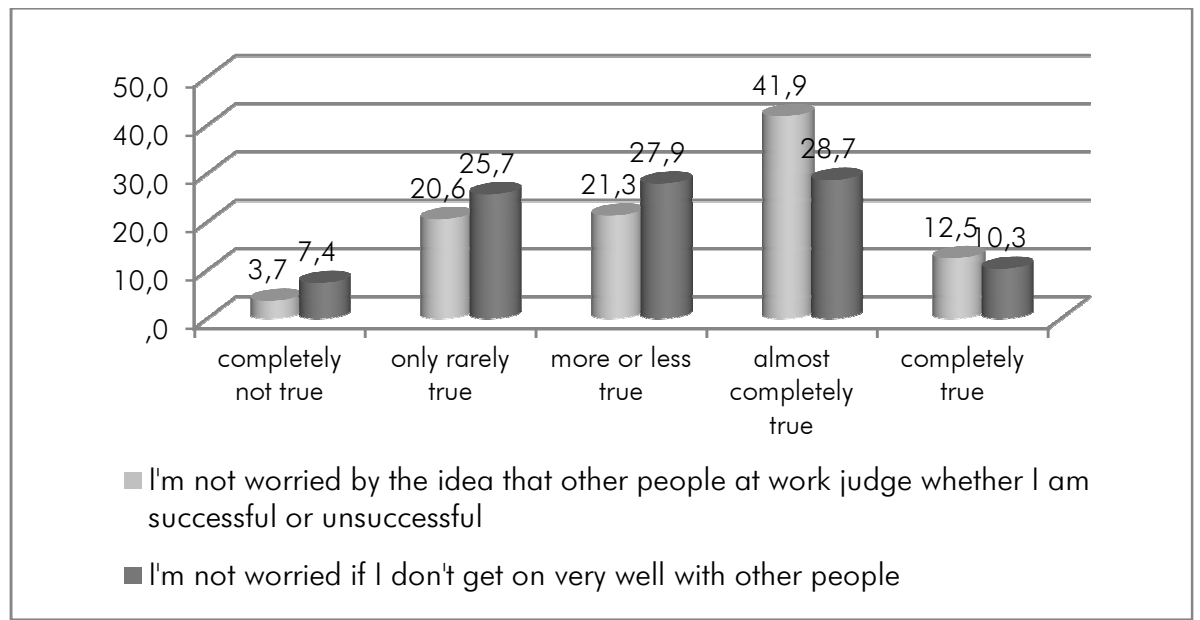

Source: own data

The results in Graph 5 indicate that over 54\% of assessed leaders stated that they are not worried by the thought of people at work judging them as successful or unsuccessful. Just under $24 \%$ of leaders are worried by the thought that people at work judge them as successful or unsuccessful. The analysis of results also indicates that just 36\% said that were not worried whether people at work judged them as successful or unsuccessful while also stating that they were not worried if they do not get on very well with other people. Twenty-one per cent of leaders said that they were worried by the both thought that people at work judged them as successful or unsuccessful, and if they did not get on very well with other people.

The results given in Graph 6 indicate that $60 \%$ of studied leaders agreed that if they make a mistake or do something clumsy that makes them look foolish, they get over it immediately. Just under $9 \%$ of leaders said they do not immediately get over making themselves look foolish. Analysing the results also indicated that $25 \%$ of studied leaders who 
immediately get over a mistake that makes them look foolish also agreed that they are not upset if some people they know have a negative opinion of them. Just under $6 \%$ of leaders said they were upset if people they knew had a negative opinion of them and that they did not immediately get over a mistake that made them look foolish. The $t$-test indicated that there was a statistically significant difference between the two variables given in Graph 6.

\section{Graph 6: Comparison of two social self-concept variables}

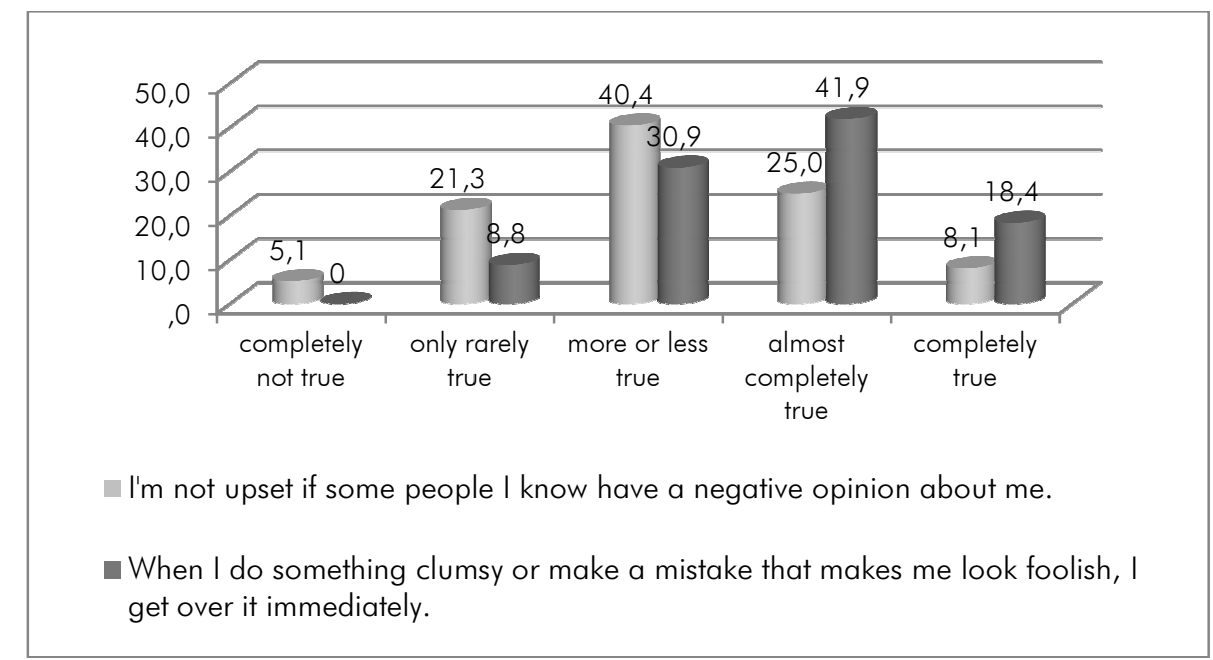

Source: own data

Physical self-concept is also important for leaders, as it relates to their internal impression of their external appearance. The results of individual variables for physical self-concept indicate that the physical self-concept of administrative unit leaders is moderately expressed and that some statistically significant differences exist between physical self-concept variables. The use of the $t$-test on physical self-concept variables indicates that statistically significant differences are found between some pairs of the variables given in Graph 7.

The results given in Graph 7 indicate that over $74 \%$ of leaders consider that they are more attractive than most people. Just over $44 \%$ said they felt they were not physically more attractive than most of their friends and colleagues. These results are interesting, particularly since friends and colleagues are the people who most affect an individual or whom an individual takes as a model, and to whose comments they are most sensitive. And if friends and colleagues are largely more physically 
attractive that the leaders, this affects their feelings or perceptions of physical attractiveness and hence effects a negative view of their body (is reflected in a moderately expressed physical self-concept). Just under 3\% of leaders wish ${ }^{20}$ they were more attractive.

\section{Graph 7: Comparison of three physical self-concept variables}

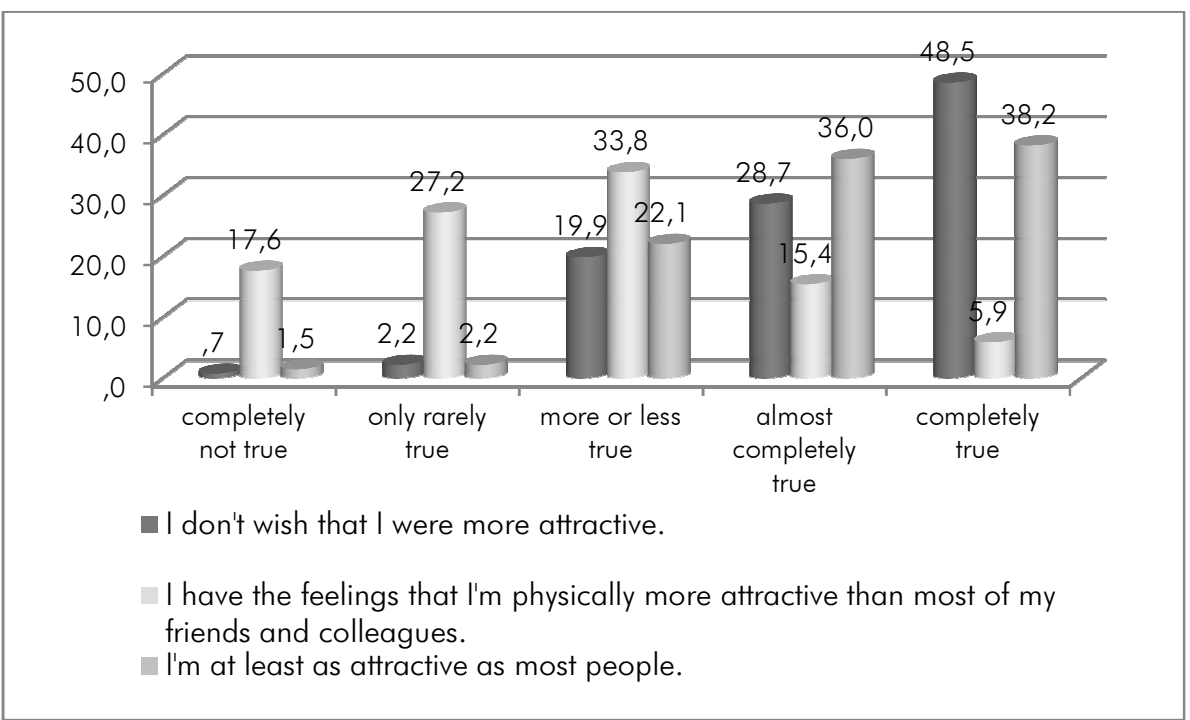

Source: own data

The results given in Graph 8 indicate that over 64\% of studied leaders consider that they are satisfied with their physical appearance, while $8.1 \%$ of administrative unit leaders did not have the best possible view of their physical appearance, which means that this view could have a negative impact on their conduct towards subordinates or on reciprocal relations.

The results given in Graph 8 indicate that over $77 \%$ of studied leaders said that they do not wish they were more attractive. Considerably fewer leaders (than those who do not wish they were more attractive) stated that they worried what others think of them. Only just over $44 \%$ of the studied leaders agreed that they are not worried what others think of them. It is logical to compare this result with the similar results achieved for the social self-concept variables. The comparative percentages are not surprising, since $38 \%$ of leaders are not upset if some people they know

20 Only $2 \%$ of leaders agreed that they wish they were more attractive and that they had a strong sense that they are not physically more attractive than their friends and colleagues. 
have a negative opinion of them, and 39\% of leaders also stated that they are not worried if they do not get on very well with other people.

Graph 8: Comparison of three physical self-concept statements

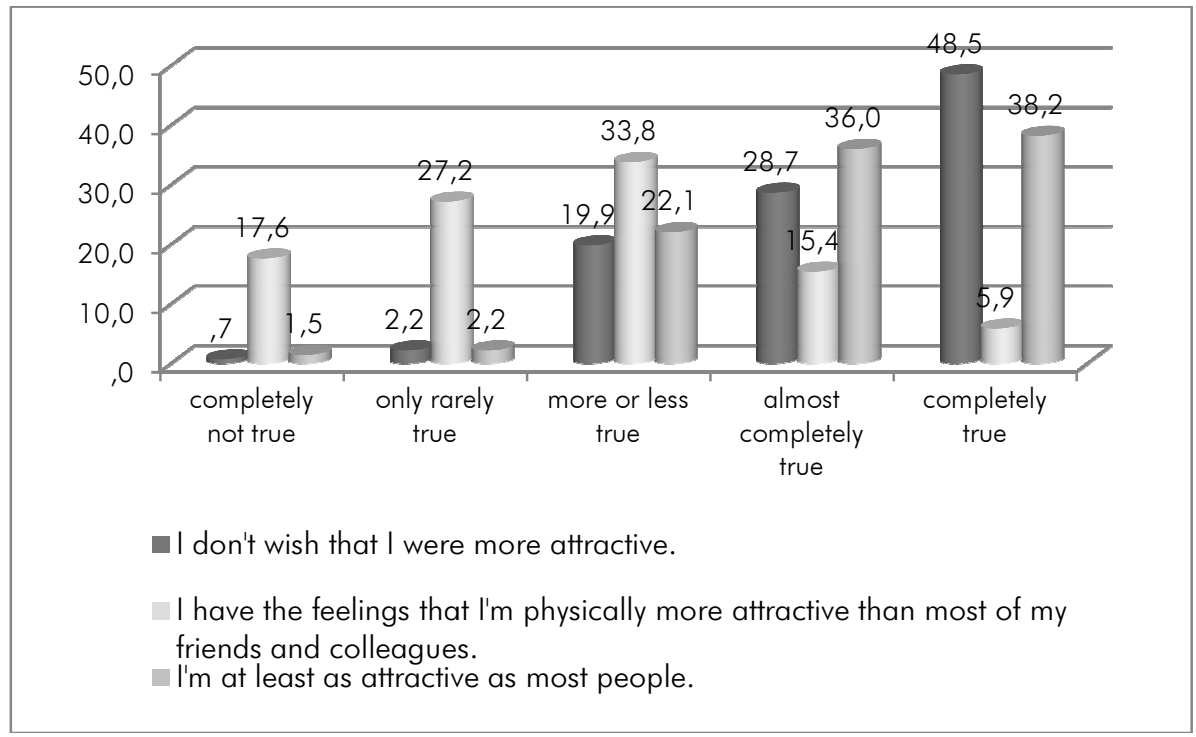

Source: own data

\subsection{Discussion}

The results of the research into the self-concept of administrative unit leaders indicate that the social and physical self-concept are the most poorly expressed (scored least). It is important for leaders to have a high score on the social self-concept scale, since this area of self-concept is linked to the image or convictions that individuals have about themselves in relations with other people (e.g. subordinates). This involves the leaders' impressions or perceptions of their popularity and their personal ability to form friendships with subordinates, their motivation and persuasion of subordinates and ability to engage with the social environment. If social self-concept is low or poor, this means that the leaders have a poor impression of themselves in relationships or begin to doubt themselves in relations to others. Since they are not as popular in society as they would like to be or perhaps subordinates rate others more highly than them, their attitude to their subordinates is harmed and they begin to question whether they are really capable of establishing relations with subordinates that are adequate for ensuring that subordinates accept and trust them. It also entails the leaders' impression of their subordinates' 
opinions of them, and how they should present themselves in social contexts.

The research results on the social self-concept of the leaders studied indicate a moderate score on the social self-concept scale. Some variables indicate results that are a cause for concern, given that leaders are expected to be capable of forming good relations with subordinates, to be respected by their subordinates and be seen as examples by them because of their skills and principles. Based on this result, one can conclude that leaders' conduct towards subordinates is limited and affects attitudes to subordinates, since if leaders doubt their own ability to establish relations with subordinates, their relations will be less successful (constant fear of whether they will be successful), while subordinates will have doubts about the leader's authority, ability and seriousness. The social self-concept results also indicate that most leaders are not subject to generalised anxiety, which consists of anxiety, worry and tension linked to the fear of accidents or unrealistic worries about health, family or work. One can conclude that those leaders (7.4\%) who state that they are tense and worried and those who consider that they have problems with depression (3.7\%) are dealing with generalised anxiety. The overall results for social self-concept indicate that the majority of leaders do not suffer from social anxiety or do not experience continual and irrational fear of social situations, in which other people could evaluate or judge them or they are not afraid of personal failure due to their mistakes.

Physical self-concept was the most poorly expressed area of selfconcept measured by the research, together with social self-concept. Physical self-concept is important for leaders, primarily in the sense that they gain a positive view of their external (physical) appearance and that they do not perceive mass media suggestions about the ideal body negatively, or in a way that could lead to a poor self-concept, since that could have a negative impact on their conduct and relations with subordinates. A positive physical self-concept can have an important impact on the formation of relations with subordinates or other people, since it can increase self-respect and contribute to successful relations. Having a negative view of one's body can lower self-confidence to the extent that people become uncomfortable with other people. A positive self-concept is desirable for leaders, since it affects self-respect and contributes to good mutual relations. The results of the research are low points scores for some physical self-concept variables. For example, 
$44 \%$ of leaders said they felt they were not physically more attractive than most of their friends and colleagues. This could mean that if leaders are generally in the company of friends and colleagues that are more attractive than them, this may have consequences for them. It can lead to jealousy and feelings of less worth or unattractiveness. Despite the fact that a leader may be attractive, it is possible the influence of friends and colleagues could be so strong compared to that of others, that the leader develops negative views of his or her external (physical) appearance. All these feelings that leaders may experience are primarily linked to a desire not to stand out in a negative manner from one's circle of friends and colleagues. This is perhaps the reason they even wish to be more attractive.

\section{Conclusion}

An important aspect of leaders, influencing their conduct and hence the conduct of their subordinates is their personality and - arising from that - their understanding and acceptance of themselves. If leaders have a positive attitude to themselves, it means they are satisfied with themselves and their life. If leaders are to understand others, they must first understand themselves. All leaders form a particular image of themselves, who they are and what they want to be. The term self-concept has been coined in the academic literature to fit this definition. Selfconcept therefore means a set of attitudes or perceptions of self that individuals form at the conscious and unconscious level, where the unconscious is covered by a layer of defence mechanisms that allow the "ego" (the conscious) to monitor the "id" (the unconscious) and creates a barrier against undesirable drives. Yet the self-concept is not just an individual's typical perception of self, but a set of complex internal processes linked to an ideal and how individuals should present themselves socially before important other people.

It is important to have a largely positive self-concept within the leadership process. By either a positive or negative self-concept, leaders affect the conduct of their subordinates and hence subordinates' satisfaction and leadership performance. Leaders who do not have a positive opinion or image of themselves have certain traits that subordinates feel. If leaders have a negative or low self-concept and do not trust, respect or value themselves, they are closed within themselves and fear contact or confrontation with people, then they will not be able 
to effectively influence subordinates. The self-concept construct has been the subject of a great deal of research work among varied groups. The related content of the self-concept construct and leadership is important in human relations and particularly in a key factor in the leadership process - the leader.

The results of this research into the self-concept of administrative unit leaders indicate their level of expression of general, emotional, social and physical self-concept and also suggest the need for further research, since only a number of areas have so far been researched. Nevertheless, it is logical that further research into self-concept should address leadership performance, and how it is influenced by self-concept.

Jernej Buzeti, MSc. is currently employed as a researcher at the Faculty of Administration at the University of Ljubliana. He has successfully completed a master's degree in 2010. Subject of his research is connected with a human resource management in public sector. He also participates in the preparation and execution of exercises.

Janez Stare, Ph.D. is Assistant Professor for organizing public sector at the Faculty of Administration University of Ljubliana, Slovenia. He has master's degree in Human Resource Management (1999) from the Faculty of organisational science University of Maribor and doctoral degree from leadership in public administration (2005) at the Faculty of Administration University of Ljubliana. His research interest is predominantly focused on contemporary issues in organizing public sector, human resource management and leadership. Since 2008 he is Vice Dean for Students Affairs at Faculty of Administration University of Ljubliana.

54 Uprava, letnik VIII, 4/2010 


\section{References}

- Adlešič, I. (1999). Samopodoba osnovnošolskih otrok. Psihološka obzoria. Vol. 8, No. 2-3, pp. 201-205.

- Ahmed, W. \& Bruinsma, M. (2006). A Structural Model of Self-concept, Autonomous Motivation and Academic Perfomance in Cross-cultural Perspective. Electronic Journal of Research in Educational Psychology. Vol. 4, No. 10, pp. 551-576.

- Akram, I. \& Akram Naseem, M. (2010). Self Concept and Social Adjustment among Physically Handicapped Persons. European Journal of Social Sciences. Vol. 15, No. 1, pp. 7-85.

- Avsec, A. (2010). Samopodoba. In: Avsec, A. (Ed.): Psihodiagnostika osebnosti. Ljubliana: Filozofska fakulteta, Oddelek za psihologijo.

- Bass, B. M. (1990): Handbook of Leadership - theory, research, and managerial applications (third edition). New York: The Free Press.

- Brajša, P. (1983). Vodenje kot medosebni proces. Ljubliana: DDU Univerzum.

- Branden, N. (2000). Samozavestno vodenje. Ljubliana: Inštitut za razvijanje osebne kakovosti.

- Burnett, P. C., Craven, R. G. \& Marsh, H. W. (1999). Enhancing students' self-concepts and related constructs: A critical longitudinal analysis capitalising on and combining promising enhancement techniques for educational settings. Retrieved from: http://eprints.qut.edu.au/27108/1/27108.pdf.

- Burns, R. B. (1979). The self concept: Theory, measurement, development and behavior. London: Longman.

- Ferbežer, I. (2008). Samopodoba mlajših nadarienih otrok. In: Ferbežer, Ivan, Težak, S. \& Korez, I. (Eds.): Samopodoba mlaiših nadarienih otrok. Ljubljana.

- Fisher, S. (1990). The evolution of psychological concepts about the body. In: Cash, Thomas F. (Ed.): Body images: development, deviance and change. New York: Goilford.

- Hattie, J. (2003). The status and direction of self-concept research: The importance of importance. Retrieved from:

http://www.education.auckland.ac.nz/webdav/site/education/shared/hattie/ docs/status-of-self-concept-research-waiheke-(2003).pdf. 
- Hellriegel, D. \& Slocum, J. W.(1996). Management. Cincinnati: SouthWestern.

- Hočevar, M., Jaklič, M. \& Zagoršek, H. (2003). Ustvarjanje uspešnega podjetja - akcijski pristop k strateškemu razmišljanju, vodenju in nadziranju. Zbirka Manager. Ljubljana: GV Založba, založniško podjetje, d.o.o.

- Katz, R. L. (1955). Skills of an effective administrator. Harvard business review. Vol. 33, No. 1, pp. 33-42.

- Kobal, D. (2000). Temelini vidiki samopodobe. Ljubliana: Pedagoški inštitut.

- Kobal, D. (1994). Samopodoba - zavestna ali tudi nezavedna razsežnost osebnosti?. Psihološka obzoria - Horizons of psychology. Vol. 3, No. 3-4, pp. 25-35.

- Kobal Grum, D. (2003). Bivanje samopodobe. Ljubljana: I2 družba za založništvo, izobraževanje in raziskovanje d.o.o.

- Kobal Grum, D. (2004). Pomen samopodobe bibliotekarja v komunikacijskem procesu. Retrieved from: http://revija-knjiznica.zbdszveza.si/lzvodi/K0403/kobal.pdf.

- Kohont, K. (2005). Custvena inteligenca pri vodenju v neprofitnih organizacijah. Ljubljana: Fakulteta za socialno delo.

- Kuhar, M. (2004). V imenu lepote - družbena konstrukcija telesne samopodobe. Ljubliana: Fakulteta za družbene vede.

- Marčič, R. (2006). Razlike med spoloma v samopodobi, samospoštovanju in nekaterih zdravju škodljivih vedenjih. Anthropos. Vol. 38, No. 3-4, pp. 63-76.

- Mayer, J. (2004). Etična načela vodenja. In: Kovač, J., Mayer, J. \& Jesenko, M. (Eds.): Stili in značilnosti uspešnega vodenja. Kranj: Moderna organizacija.

- Maxwell, J. C. (2007). 21 nepogrešljivih lastnosti vodje: postanite človek, ki mu bodo drugi hoteli slediti. Ljubljana: Lisac\&Lisac d.o.o.

- Musek, J. (1993a). Znanstvena podoba osebnosti. Ljubljana: Educy d.o.o.

- Musek, J. (1993b). Osebnost pod drobnogledom. Maribor: Obzorja.

- Musek, J. (2005). Psihološke dimenzije osebnosti. Ljubliana: Filozofska fakulteta, Oddelek za psihologijo.

- Nastran Ule, M. (1994). Temelii socialne psihologije. Zbirka Alfa. Ljubliana: Znanstveno in publicistično središče.

56 Uprava, letnik VIII, 4/2010 
- Northouse, P. G. (2007). Leadership: theroy and practice. London: Sage Publications.

- Račnik, M. (2008). Samopodoba in prepričanje. Retrieved from: http://www.vodja. net/index.php? blog $=1 \& p=187 \&$ more $=1 \& c=1 \&+b=1 \& p$ $b=1$.

- Samuel, W. (1981). Personality, searching for the sources of human behavior. New York: McGraw-Hill, Inc.

- Stare, Janez (2005). Povezanost osebnostnega potenciala za vodenje z uspešnostjo vodenja v organih državne uprave. Ph. D.. Ljubljana: Univerza v Ljubliani, Fakulteta za upravo.

- Stare, J. \& Seljak, J. (2006). Vodenje liudi v upravi: povezanost osebnostnega potenciala za vodenje z uspešnostjo vodenja. Ljubliana: Fakulteta za upravo.

- Yukl, G. A. (2002). Leadership in organizations. New York: Prentice - Hall International.

- Zimbardo, P. G. \& Gerrig, R. J. (1996). Psychology and Life, Fourteenth Edition. New York: HarperCollins Publishers Inc.

- Zupančič, M. (1993). Razvojne naloge mladostnika in institucionalno izobraževanje. Psihološka obzoria. Vol. 2, No. 3-4, pp. 207-213. 